\title{
Thiourea Catalyzed Organocatalytic Enantioselective Michael Addition of Diphenyl Phosphite to Nitroalkenes
}

\author{
Ana Alcaine, ${ }^{a}$ Eugenia Marqués-López, ${ }^{b}$ Pedro Merino, ${ }^{a}$ Tomás Tejero ${ }^{a}$ and Raquel P. Herrera* ${ }^{a, c}$
}

${ }_{5}$ Bifunctional thiourea catalyzes the enantioselective Michael addition reaction of diphenyl phosphite to nitroalkenes. This methodology provides a facile access to enantiomerically enriched $\beta$ nitrophosphonates, precursors for the preparation of synthetically and biologically useful $\beta$ aminophosphonic acids. DFT level of computational calculations invoke the attack of the diphenyl phosphite to the nitroolefin by the $R e$ face, this give light to this scarcely explored process update in the 10 literature. The computational calculations support the absolute configuration obtained in the final adducts.

\section{Introduction}

Due to the immense progress in the scientific community, the claim in the organic synthesis has been shifted to the design and synthesis of more complex structures and important targets 15 making essential the search for new methods and new efficient processes. ${ }^{[1]}$ Organocatalysis has emerged as a powerful tool and as an efficient solution for the rapid and stereoselective construction of significant chiral entities. ${ }^{[2,3]}$ In the last decade, the enantioselective synthesis of $\alpha$ - and $\beta$-aminophosphonic acids 20 and their phosphonate esters has received significant attention owing to their biological activities as structurally analogues to $\alpha$ and $\beta$-amino acids. ${ }^{[4,5]}$ It is not surprising that the absolute configuration of the stereogenic $\alpha$ - or $\beta$-carbon in these phosphonyl compounds strongly influences their biological ${ }_{25}$ properties. ${ }^{[6]}$ In this context, great efforts have been focused toward the development of excellent asymmetric methods for the synthesis of enantiomerically pure $\alpha$-aminophosphonic acids. ${ }^{[4,7]}$ However, the strategies for the synthesis of $\beta$-aminophosphonic acids has been less studied ${ }^{[5]}$ and only a few examples based in 30 organocatalytic protocols have been scarcely investigated to date. ${ }^{[8]}$ The Michael addition of phosphorus compounds to nitroolefins provides a straightforward and convenient method for synthesizing P-C bonds. ${ }^{[9,10]}$ Two interesting and pioneer organocatalytic enantioselective methods concerning Michael 35 addition of diphenyl phosphite have been reported using chiral guanidine 1 and quinine 2 (Figure 1). ${ }^{[8 a, b]}$ Very recently, Rawal and co-workers reported the Michael addition of phosphite to nitroalkenes catalyzed by squaramide $3 .^{[8 c]}$ Therefore, the development of new and efficient catalytic methodologies to 40 obtain $\beta$-nitrophosphonates are still of remarked importance. Among the great number of organocatalysts developed until now, thioureas/ureas have attracted a great attention in the scientific community from pioneering examples reported by Curran and co-workers, ${ }^{[11]}$ as suitable catalysts for a great number of efficient ${ }_{45}$ processes. $^{[12]}$ Herein, we report the organocatalytic enantioselective Michael addition of diphenyl phosphites to nitroolefins affording $\beta$-nitrophosphonates enantiomerically enriched using bifunctional thiourea 4a. Michael adducts could be further conveniently transformed to chiral $\beta$-aminophosphonic 50 acids following the procedures previously reported in the literature. $^{[8 \mathrm{a}, \mathrm{b}]}$

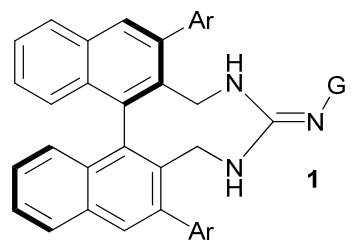<smiles>O=c1c(Nc2ccc(C(F)(F)F)cc2)c(N[C@@H]2CCCC[C@H]2N2CCCCC2)c1=O</smiles>
$\mathrm{G}=\mathrm{Ph}_{2} \mathrm{CH}-, \quad \mathrm{Ar}=3,5-\mathrm{t}-\mathrm{Bu}_{2} \mathrm{C}_{6} \mathrm{H}_{3}-$<smiles>C=CC1CC2CCC1N2CC(O)c1ccnc2ccc(OC)cc12</smiles><smiles>CN(C)[C@H]1CCCC[C@H]1NC(=S)Nc1cc(C(F)(F)F)cc(C(F)(F)F)c1</smiles>

Fig. 1 Catalysts employed in the phospha-Michael addition reaction

\section{Results and discussion}

${ }_{55}$ Based on our experience using thiourea catalysts ${ }^{[13]}$ and the demonstrated ability of these molecules activating nitro groups as proposed by several authors ${ }^{[14,15]}$ we decided to explore and study these structures in the asymmetric phospha-Michael reaction of nitroalkenes (Figure 2, Table 1). Thioureas $\mathbf{4 b}$-h were first 60 synthesized following our previously reported procedure, depicted in Scheme 1. ${ }^{[13 b, e]}$ This easy method allows access to a great variety of this kind of structuresA tab stop has been set in the style to allow for easy indenting of text (although the first paragraph and paragraphs that follow headings should not be ${ }_{65}$ indented).

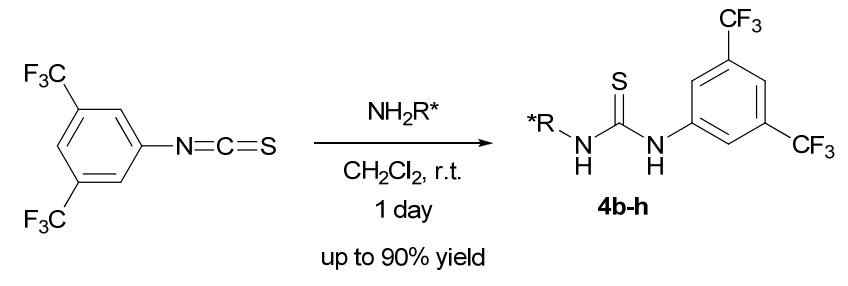

Scheme 1 Synthesis of chiral thioureas 
These synthesized thioureas (4b-h), as well as others commercially available (4a and $\mathbf{4 i - k}$ ) (Figure 2) were tested as catalysts in a model hydrophosphonylation reaction using trans$\beta$-nitrostyrene (5a) as substrate, and the results are summarized in
5 Table 1.<smiles>[R]C(=S)Nc1ccc2ccccc2c1-c1c(NC([R])=S)ccc2ccccc12</smiles>

$4 \mathrm{~b}$

$\mathrm{R}=\mathrm{NH}-3,5-\left(\mathrm{CF}_{3}\right)_{2} \mathrm{C}_{6} \mathrm{H}_{3}$<smiles>[R]C(=S)NC(CO)Cc1ccccc1</smiles>

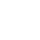<smiles>[R]C(=S)NC1CCCCC1NC([R])=S</smiles>

$4 d$<smiles>[R]C(=S)NC1c2ccccc2CC1[R]</smiles>

4e $\mathrm{R}=\mathrm{OH}$

4f $\mathrm{R}=\mathrm{H}$<smiles>O[C@H]1Cc2ccccc2[C@H]1NC(=S)Nc1cc2ccccc2c2ccccc12</smiles>

$4 \mathrm{~g}$<smiles>[R]C(=S)N[C@H](c1ccnc2ccc(OC)cc12)C1CC2CC1CC2C=C</smiles>

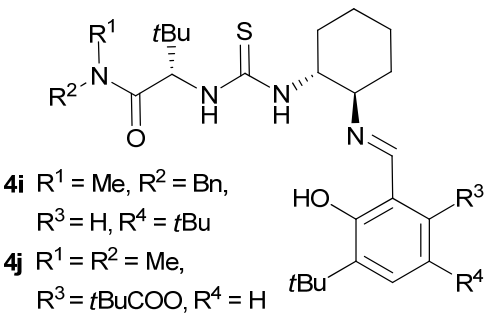<smiles>Cc1ccc(-c2ccccc2)n1C1CCCC[C@H]1NC(=S)NC(C(=O)N(CC(C)C)CC(C)C)C(C)(C)C</smiles>

$4 \mathbf{k}$

Fig. 2 Thiourea catalysts tested

Table 1 Screening of thiourea catalysts $4 \mathbf{a}-4 \mathbf{k} .^{a}$

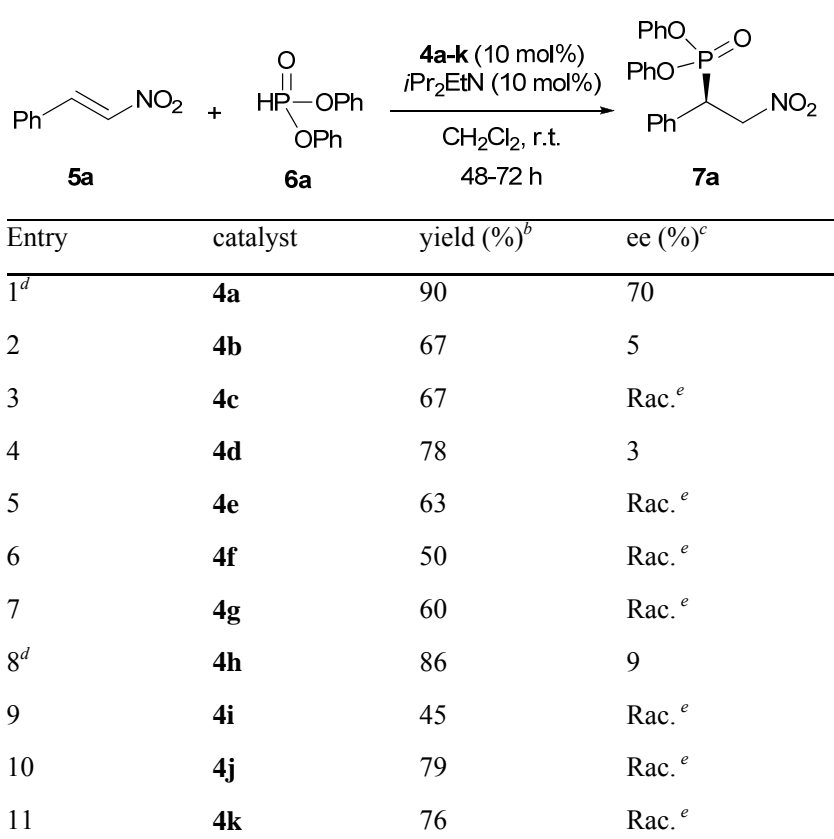

${ }^{a}$ Experimental conditions: To a solution of nitroalkene (5a) $(0.4 \mathrm{mmol})$ and corresponding catalyst $\mathbf{4 a - k}(10 \mathrm{~mol} \%)$ in $\mathrm{CH}_{2} \mathrm{Cl}_{2}(1 \mathrm{~mL}), i \mathrm{Pr}_{2} \mathrm{EtN}$ $(10 \mathrm{~mol} \%)$ and diphenyl phosphite $6 \mathbf{a}(0.4 \mathrm{mmol})$ were added at room 15 temperature. ${ }^{b}$ After isolation by column chromatography. ${ }^{c}$ Determined by chiral HPLC analysis (Chiralpak IA). ${ }^{d}$ Reaction performed in absence of $i \operatorname{Pr}_{2} \mathrm{EtN}^{e}{ }^{e}$ Racemic sample.

Among all thioureas tested in this process, only 4a afforded promising results in terms of both reactivity and 20 enantioselectivity (Table 1 , entry 1 ). ${ }^{[16]}$ In the other cases, the addition of an external base was always required in order to observe reactivity, ${ }^{[17]}$ except for catalyst $\mathbf{4 h},{ }^{[18]}$ which also has 1

You can also put lists into the text. a Brønsted base moiety in its structure (Table 1, entry 8). However unfortunately, the final 25 products were obtained with very poor enantioselectivities. On the basis of this observation, it is conceivable that the presence of the Brønsted base and the thiourea moiety placed on the right position in the same molecular structure is crucial for the success of this protocol. Maybe, due to formation of a rigid transition 30 state, leading to higher values of enantioselectivity.

Catalysts $\mathbf{4 c}$, $\mathbf{4 e}$, and $\mathbf{4 g}$ were used expecting a bifunctional mode of action of these structures, since the possible bifunctional character of such catalysts has been already proposed when the thiourea moiety and the hydroxy group, which would activate the ${ }_{35}$ nucleophile, are present in the same skeleton (Figure 3). ${ }^{[13 \mathrm{~b}, \mathrm{e}]}$ However in this case, the coordination of the nucleophile with the $\mathrm{H}$ of the hydroxyl group seems to be neither effective nor efficient enough to promote the reaction in an enantioselective way.

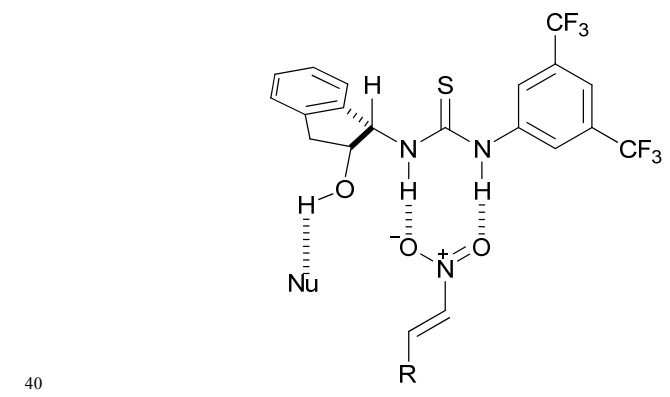

Fig. 3 Bifunctional mode of action

The bifunctional role that catalyst $\mathbf{4 h}$ may play in similar processes has been also previously proposed and discussed. ${ }^{[13 \mathrm{~d}, 18]}$ In fact, in the current reaction, catalyst $\mathbf{4 h}$ gave slighlty the 45 second best result, which is in agreement with the importance of having both moeties (the Brønsted base and the thiourea) in the same structure. Furthermore, bis-thiourea catalyst $\mathbf{4 d}^{[19]}$ has been also invoked to react as bifunctional catalyst interacting with both 
nucleophile and electrophile by hydrogen-bonds. To further explore the viability of this phospha-Michael addition, different parameters were investigated using trans- $\beta$-nitrostyrene (5a) as the test substrate and the previous best catalyst (4a) (Table 2).

5 Table 2 Screening for the organocatalytic asymmetric Michael addition reaction of phosphite $\mathbf{6 a}$ to trans- $\beta$-nitrostyrene (5a). ${ }^{a}$

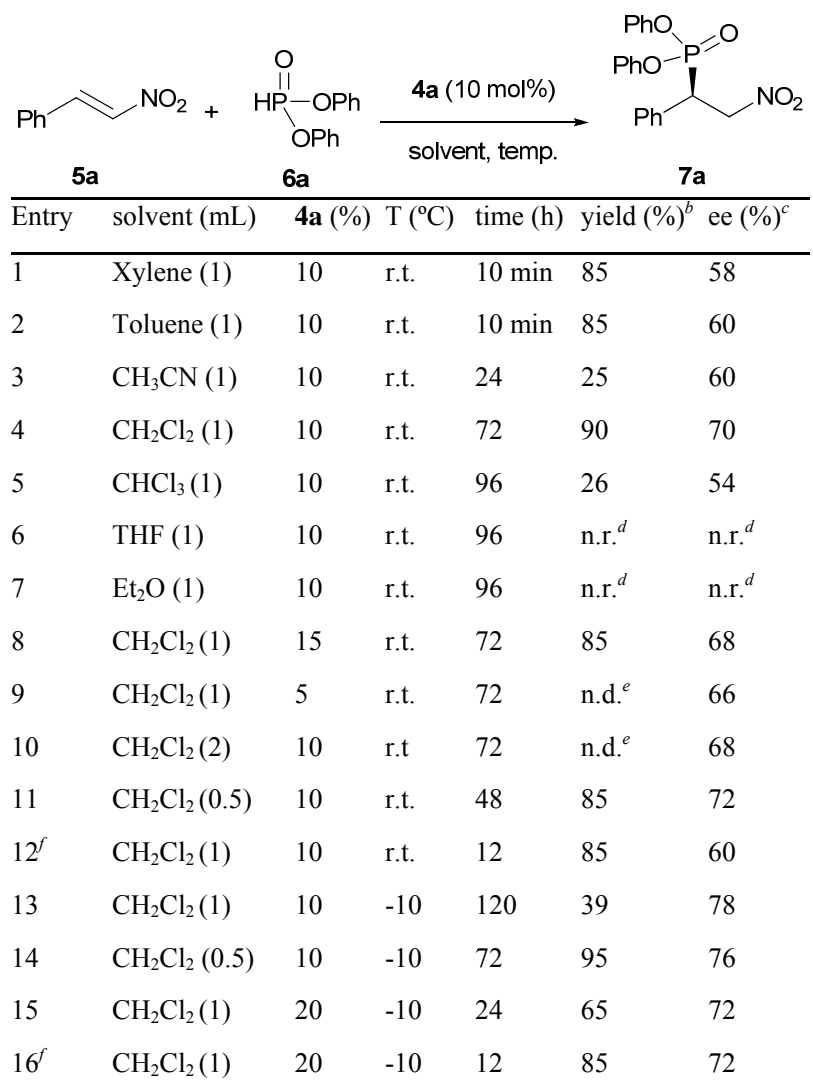

${ }^{a}$ Experimental conditions (unless specified): To a solution of nitroalkene (5a) $(0.4 \mathrm{mmol})$ and catalyst $4 \mathbf{a}(10 \mathrm{~mol} \%)$ in the corresponding solvent $(1 \mathrm{~mL})$, diphenyl phosphite $6 \mathbf{6}(0.4 \mathrm{mmol})$ was added at room 10 temperature. $^{b}$ After isolation by column chromatography. ${ }^{c}$ Determined by chiral HPLC analysis (Chiralpak IA). ${ }^{d}$ Not reaction observed. ${ }^{\mathrm{e}}$ Not determined. ${ }^{f} 2$ equiv. of diphenyl phosphite $\mathbf{6 a}$.

In an initial screening of solvents at room temperature, while $\mathrm{THF}$ and $\mathrm{Et}_{2} \mathrm{O}$ showed not to be effective for this reaction (entries 15 6-7), toluene, xylene, $\mathrm{CH}_{3} \mathrm{CN}, \mathrm{CHCl}_{3}$, and $\mathrm{CH}_{2} \mathrm{Cl}_{2}$ provided the final product with promising values of enantioselectivity (entries 1-5). Finally, $\mathrm{CH}_{2} \mathrm{Cl}_{2}$ was the solvent of choice for further variations, since it led to the highest yield and enantioselectivity (entry 4), even when longer reaction time was required compared 20 with toluene or xylene (entries 1-2). Variation of the catalyst loading (entries 8-9), dilution of the reaction mixture (entry 10) or the addition of an excess of phosphite (entry 12) had a negative effect on the enantioselectivity and the yield. On the other hand, increasing the concentration accelerated the reaction giving ${ }_{25}$ comparable results (entry 11). Lowering the temperature to -10 ${ }^{\circ} \mathrm{C}$ improved the enantioselectivity at the expense of reactivity and yield (entry 13). Thus, the combination of both variations (concentration and cooling down to $-10{ }^{\circ} \mathrm{C}$ ) led to a slight increase in the asymmetric induction as well as in the the yield, 30 providing finally the best reaction conditions (entry 14). However, due to the interesting short reaction time required when toluene was used (Table 2, entry 2), we could not discard this solvent before further investigations were carried out (Table 3 ).

Table 3 Screening of different reaction conditions using toluene as 35 solvent. $^{a}$

\begin{tabular}{|c|c|c|c|c|c|}
\hline $5 a$ & $-\mathrm{NO}_{2}+$ & $\begin{array}{l}\text {-OPh } \\
\text { OPh } \\
\text { aa }\end{array}$ & $\begin{array}{l}\mathbf{4 a}(10 \mathrm{~mol} \% \\
\text { Toluene, ten }\end{array}$ & $\mathrm{Ph}$ & $7 a$ \\
\hline$\overline{\text { Entry }}$ & solvent $(\mathrm{mL})$ & $\mathbf{6 a}$ (eq.) & time (h) & yield $(\%)^{b}$ & ee $(\%)^{c}$ \\
\hline 1 & 2 & 1 & 12 & 62 & 66 \\
\hline 2 & 2.5 & 1 & 120 & 34 & 64 \\
\hline 3 & 3 & 1 & 120 & n.d. ${ }^{d}$ & 60 \\
\hline $4^{h}$ & 1 & 1 & 72 & n.d. ${ }^{d}$ & 66 \\
\hline $5^{i}$ & 1 & 1 & 12 & 78 & 62 \\
\hline 6 & 1 & 2 & $5 \mathrm{~min}$ & 84 & 62 \\
\hline 7 & 2 & 2 & $5 \mathrm{~min}$ & 80 & 60 \\
\hline 8 & 2 & 0.9 & 12 & 80 & 60 \\
\hline
\end{tabular}

${ }^{a}$ Experimental conditions: To a solution of nitroalkene (5a) $(0.4 \mathrm{mmol})$ and catalyst $4 \mathbf{a}(10 \mathrm{~mol} \%)$ in toluene $(1 \mathrm{~mL})$, diphenyl phosphite $6 \mathbf{a}(0.4$ mmol) was added. ${ }^{b}$ After isolation by column chromatography. ${ }^{c}$ Determined by chiral HPLC analysis (Chiralpak IA). ${ }^{d}$ Not determined. ${ }^{h}$ $405 \mathrm{~mol} \%$ of catalyst $4 \mathrm{a} .{ }^{i}$ Reaction performed at $0{ }^{\circ} \mathrm{C}$.

Unfortunately, any of the variations performed in the concentration of the solution (entries 1-3,7-8), catalyst loading (entry 4), temperature (entry 5), and amount of diphenyl phosphite (6a) (entry 6-8) did not afford better results in 45 comparison with those achieved using $\mathrm{CH}_{2} \mathrm{Cl}_{2}$ as solvent. We observed the fast precipitation of the final product in the reaction media, due to its insolubility in toluene. This fact accelerates the process but it does not provide better enantioselectivity.

The effect of other different nucleophilic dialkyl phosphites 50 [diethyl phosphite (6b), dimethyl phosphite (6c), diisopropyl phosphite (6d) and dibenzyl phosphite (6e)] were also explored in order to improve the enantioselectivity of the Michael reaction (Figure 4).

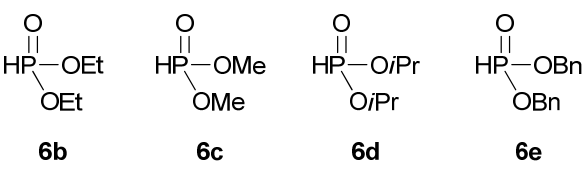

Fig. 4 Dialkyl phosphites tested

However, under the best reaction conditions, after 3 days, any of these dialkyl phosphites (6b-e) were reactive enough. Thus, only diphenyl phosphite (6a) furnished the corresponding final product $7 \mathbf{a}$ with good results. The lack of reactivity and the ${ }_{60}$ dramatic descent of the reaction rates using these dialkyl phosphites (6b-e) might be due to the drastic variation of its $\mathrm{p} K_{\mathrm{a}}$ values, ${ }^{[20]}$ as we observed in a previous work. ${ }^{[21]}$

Having established the optimal reaction conditions, we further explored the scope of this 1,4-Michael addition for various ${ }_{65}$ substituted nitroolefines 5b-l. Corresponding derivatives 7a-l were furnished with very good yields and good enantioselectivities in $\mathrm{CH}_{2} \mathrm{Cl}_{2}$ at $-10{ }^{\circ} \mathrm{C}$ (Table 4). 
Table 4 Organocatalytic enantioselective 1,4-Michael addition of phosphite 6a to nitroalkenes 5a-I catalyzed by thiourea $4 a^{a}$

\begin{tabular}{|c|c|c|c|c|}
\hline 5a-I & & \multicolumn{2}{|c|}{$\mathrm{CH}_{2} \mathrm{Cl}_{2,}-10^{\circ} \mathrm{C}$} & \multirow{2}{*}{$\frac{7 a-I}{\text { ee }(\%)^{c}}$} \\
\hline Entry & $\mathrm{R}$ & time (days) & yield $(\%)^{b}$ & \\
\hline 1 & $\mathrm{Ph}(7 \mathbf{a})$ & 3 & 95 & 76 \\
\hline 2 & $4-\mathrm{MeC}_{6} \mathrm{H}_{4}(\mathbf{7 b})$ & 3 & 81 & 74 \\
\hline 3 & $4-\mathrm{MeOC}_{6} \mathrm{H}_{4}(7 \mathrm{c})$ & 3 & 79 & 78 \\
\hline 4 & $2-\mathrm{MeOC}_{6} \mathrm{H}_{4}(\mathbf{7 d})$ & 3 & 75 & 73 \\
\hline 5 & $2-\mathrm{CF}_{3} \mathrm{C}_{6} \mathrm{H}_{4}(7 \mathbf{e})$ & 3 & 79 & 76 \\
\hline 6 & $4-\mathrm{ClC}_{6} \mathrm{H}_{4}(\mathbf{7 f})$ & 3 & 87 & 73 \\
\hline 7 & $4-\mathrm{FC}_{6} \mathrm{H}_{4}(7 \mathbf{g})$ & 4 & 60 & 72 \\
\hline 8 & 2-furyl (7h) & 3 & 67 & 76 \\
\hline 9 & $4-\mathrm{BrC}_{6} \mathrm{H}_{4}(\mathbf{7 i})$ & 3 & 79 & 76 \\
\hline 10 & $4-\mathrm{BnOC}_{6} \mathrm{H}_{4}(\mathbf{7 j})$ & 3 & 81 & 78 \\
\hline 11 & Cy (7k) & 3 & 82 & 72 \\
\hline 12 & $\mathrm{PhCH}_{2} \mathrm{CH}_{2}$ (7l) & 3 & 60 & 68 \\
\hline
\end{tabular}

${ }^{a}$ See Experimental Section. ${ }^{b}$ After isolation by column chromatography. ${ }^{c}$ Determined by chiral HPLC analysis (Chiralpak IA and IB).

An enantioselectivity/temperature profile showed that in all cases a small improvement on the enantioselectivity was posible after longer reaction time, by running the reactions at $-10^{\circ} \mathrm{C}$. As illustrated in Table 4, nitroolefines $\mathbf{5 a - 1}$ underwent conjugate addition with diphenyl phosphite $\mathbf{6 a}$ in the presence of catalyst $\mathbf{4 a}$

10 within 3 reaction days with high yields and good enantiomeric ratio (up to $78 \%$ ). The steric hindrance and the electronic environment influence only slightly on the enantioselectivity of this process, which was almost independent of the aryl group (entries 1-10). Although with alkyl substituents the 15 enantioselectivity seems to be somewhat lower (entries 11-12). These results are comparable to those previously reported by Wang and co-workers, but shorter reaction times and a less drastic decrease in temperature $\left(-55^{\circ} \mathrm{C}\right)$ were required, ${ }^{[8 \mathrm{a}]}$ which saves energy and time management. Unfortunately, we could not 20 improve the excellent results reported by Terada, ${ }^{[8 b]}$ and Rawal ${ }^{[8 c]}$ groups. However, the readily accessible thioureas, compared with the more tedious preparation of their catalysts, reinforces the simplicity and viability of our procedure. The absolute configuration of the Michael adducts 7a-l was determined by 25 comparison of the optical rotation values with those previously reported in the literature for the same products. ${ }^{[8]}$

On the basis of the obtained results, we envisioned that catalyst 4a could act in a bifunctional fashion, as previously proposed in the literature. ${ }^{[22]}$ The activation of nitroolefins by thiourea $\mathbf{4 a}$ has 30 been demonstrated earlier in other processes ${ }^{[16,23]}$ and kinetic studies indicated the bifunctional character of this structure in Michael reactions. ${ }^{[16 \mathrm{c}]}$ In order to give additional support to this hypothesis we performed calculations at DFT level (B3LYP/6$\left.31+\mathrm{G}^{*}\right) \cdot{ }^{[24]} \mathrm{We}$ assumed that the enantioselectivity of the reaction 35 is controlled during the C-P bond formation between the activated nitroalkene and the nucleophile. We have studied the approach of dimethyl phosphate, which has been employed as the model reagent, to both $R e$ and $S i$ faces of the nitroalkene. For each enantiotopic face, the attack can occur from above or below, 40 leading to four transition states. Among these transition states, those corresponding to the upper attack (TS-1 and TS-2) are lower in energy (Figure 5). The key proton abstraction from the developing phosphite anion by the dimethylamino group ${ }^{[25]}$ helps in stabilizing the transition states and it is responsible of the 45 enantioselective approach of the nucleophile to the nitroalkene. From the two possible orientations of the double bond, that corresponding to the $R e$ attack and leading to $(R)$-isomer, resulted the most stable by $1.39 \mathrm{kcal} / \mathrm{mol}$, thus being in good qualitative agreement with the experimental results.

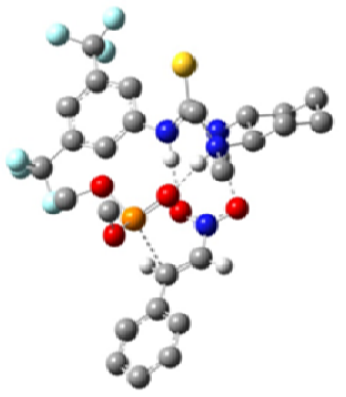

TS-1

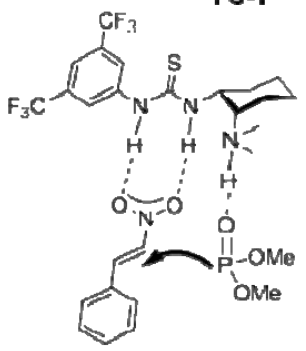

$0.00 \mathrm{Kcal}$

Re attack

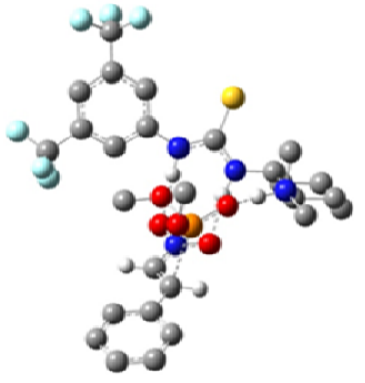

TS-2

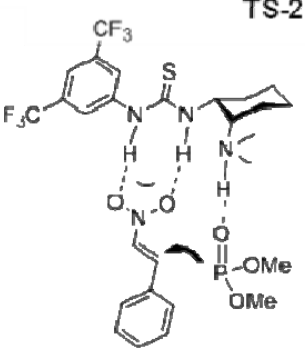

$1.39 \mathrm{Kcal}$

Si attack
50

Fig. 5 Transition state models

In contrast to the $S i$-facial attack, $R e$-facial approach of the phosphite is located at the less sterically demanding upper righthand quadrant. Therefore, TS-1 is more stabilized than TS-2 55 because a lower steric repulsion between the phosphite nucleophile and the inside-oriented phenyl group of the nitroalkene. These results are also in agreement with similar theoretical studies reported by Papai and co-workers ${ }^{[25 \mathrm{a}]}$ for the thiourea catalyzed nucleophilic addition of acetylacetone to 60 nitrostyrene. The C-P distances in the transition states were found to be very similar, $2.76 \AA$ and $2.80 \AA$ for TS-1 and TS-2, respectively indicating early transition states in which the electrostatic interaction between the phosphite and the dimethylamino group at the catalyst is crucial for approaching the 65 reagents. The possibility of hydrogen bonding between the nitro group and the thiourea moiety through an only oxygen atom as recently proposed by other authors ${ }^{[26]}$ has also been considered, but in all cases higher energy stationary points have been found in close agreement with previous calculations made by Papai in 70 which it was demonstrated the preference by a substrate binding through bidentate $\mathrm{H}$-bonds with the nitroalkene. ${ }^{[25 a]}$ Higher level calculations considering solvent correction are undergoing in our group to confirm these preliminary results and will be reported in 
due course.

\section{Conclusions}

In summary, we have reported a simple and enantioselective organocatalytic phospha-Michael reaction catalyzed by 5 commercially available Takemoto's thiourea catalyst $\mathbf{4 a}$. Thus, this methodology provides a facile access to the corresponding enantiomerically enriched $\beta$-nitrophosphonates in good yields. The limited number of catalytic enantioselective methods for the synthesis of $\beta$-nitrophosphonates by straightforward 10 hydrophosphonylation of nitroalkenes, ${ }^{[8,27]}$ and the high synthetic versatility of these products make this new approach very attractive for the synthesis of optically active $\beta$-aminophosphonic acids. DFT level of computational calculations appeal to the attack of the diphenyl phosphite to the nitroolefin by the $R e$ face,

15 this shed light on this process which has been scarcely explored up to now in the literature. We have invoked the importance, efficiency and utility of bifuctional catalysts and we will study the design and synthesis of new bifuncional thioureas. Future research will be carried out concerning to the improvement of 20 enanantiocontrol of this process.

Due to the extremely simple operational procedure our methodology is very accessible and it increases the utility and interest of the work in this growing area of the use of thioureas as organocatalysts.

\section{${ }_{25}$ Acknowlegments}

We thank the Ministry of Science and Innovation (MICINN. Madrid. Spain. Projects CTQ2009-09028 and CTQ2010-19606) and the Government of Aragón (Zaragoza. Spain. Project PI064/09 and Research Groups, E-10) for financial support of our 30 research. E. M.-L. thanks Alexander von Humboldt Foundation for a postdoctoral fellowship and CSIC for a JAE-Doc contract. We are also grateful to David Roca-López (Universidad de Zaragoza) for his help and encouragement. R. P. H. thanks the Aragón I+D Foundation for her permanent contract.

\section{${ }_{35}$ Experimental section}

\section{General Information}

Purification of reaction products was carried out by flash chromatography using silical-gel $(0.040-0.063 \mathrm{~mm})$. Analytical thin layer chromatography was performed on $0.25 \mathrm{~mm}$ silical gel ${ }_{40} 60-\mathrm{F}$ plates. ${ }^{1} \mathrm{H}-\mathrm{NMR}$ spectra were recorded at $400 \mathrm{MHz}$; ${ }^{13} \mathrm{C}$-NMR spectra were recorded at $100 \mathrm{MHz}$ and $75 \mathrm{MHz} ; \mathrm{CDCl}_{3}$ as solvent. Chemical shifts were reported in the $\delta$ scale relative to residual $\mathrm{CHCl}_{3}$ (7.26 ppm) for ${ }^{1} \mathrm{H}-\mathrm{NMR}$ and to the central line of $\mathrm{CDCl}_{3}(77.0 \mathrm{ppm})$ for ${ }^{13} \mathrm{C}-\mathrm{NMR}$.

${ }_{45}$ Materials. All commercially available solvents and reagents were used as received. Chiral thioureas catalysts were obtained following the literature procedure: $\mathbf{4 b},{ }^{[28]} \mathbf{4} \mathbf{c},{ }^{[13 \mathrm{e}]} \mathbf{4 d},{ }^{[18 \mathrm{a}]} \mathbf{4 e - g},{ }^{[13 \mathrm{e}]}$ and $\mathbf{4 h} \cdot{ }^{[29]}$ The ${ }^{1} \mathrm{H}$ and ${ }^{13} \mathrm{C}-\mathrm{NMR}$ spectra for the compounds $\mathbf{7 a -}$ $\mathbf{d , h}-\mathbf{i}, \mathbf{k}, \mathbf{l}$ are consistent with values previously reported in the 50 literature. ${ }^{[8]}$
Representative experimental procedure for enantioselective 1,4-addition reaction of diphenyl phosphite (6a) with nitroalkenes (5a-l) catalyzed by thiourea $4 a$.

To a solution of nitroalkene (5a-l) $(0.4 \mathrm{mmol})$ and catalyst $4 \mathbf{a}$ (10 $55 \mathrm{~mol} \%)$ in $\mathrm{CH}_{2} \mathrm{Cl}_{2}(0.5 \mathrm{~mL})$, in a test tube, diphenyl phosphite (6a) $(0.4 \mathrm{mmol})$ was added. After the appropriate reaction time, at -10 ${ }^{\circ} \mathrm{C}$, the residue was purified by silica gel chromatography $\left(\mathrm{SiO}_{2}\right.$, hexane/EtOAc 7:3) to afford the adducts $7 \mathbf{a}-\mathbf{l}$ as white solid. Yields and spectral and analytical data for compounds $\mathbf{7 a - 1}$ are as 60 follows:

\section{(R)-Diphenyl 2-nitro-1-phenylethylphosphonate (7a)}

Following the general procedure, compound 7a was obtained after 3 days at $-10{ }^{\circ} \mathrm{C}$ as a white solid in $95 \%$ yield. Mp. $154-160{ }^{\circ} \mathrm{C}$. The ee of the product was determined by HPLC ${ }_{65}$ using a Daicel Chiralpak IA column $(n$-hexane $/ i$-PrOH $=60: 40$, flow rate $0.5, \mathrm{~mL} / \mathrm{min}, \lambda=254 \mathrm{~nm}$ ): $\tau_{\text {major }}=18.7 \mathrm{~min} ; \tau_{\text {minor }}=21.0$ min. HRMS calcd for $\mathrm{C}_{20} \mathrm{H}_{18} \mathrm{NNaO}_{5} \mathrm{P} 406.0820$; found 406.0812 $\left[\mathrm{M}^{+}+\mathrm{Na}\right] .[\alpha]_{\mathrm{D}}^{22}=-1.24\left(c 1.0, \mathrm{CHCl}_{3}, 76 \%\right.$ ee $)$. The ${ }^{1} \mathrm{H}$ and

${ }^{13} \mathrm{C}$ NMR spectra are consistent with values previously reported 70 in the literature. ${ }^{[8 a, b]}$

\section{(R)-Diphenyl 2-nitro-1-p-tolylethylphosphonate (7b)}

Following the general procedure, compound $7 \mathbf{b}$ was obtained after 3 days at $-10{ }^{\circ} \mathrm{C}$ as a white solid in $81 \%$ yield. M.p. $116-119^{\circ} \mathrm{C}$. The ee of the product was determined by HPLC 75 using a Daicel Chiralpak IB column $(n$-hexane $/ i-\operatorname{PrOH}=90: 10$, flow rate $1 \mathrm{~mL} / \mathrm{min}, \lambda=254 \mathrm{~nm}$ ): $\tau_{\text {major }}=22.1 \mathrm{~min} ; \tau_{\text {minor }}=15.3$ min. HRMS calcd for $\mathrm{C}_{21} \mathrm{H}_{20} \mathrm{NNaO}_{5} \mathrm{P} 420.0977$; found 420.0964 $\left[\mathrm{M}^{+}+\mathrm{Na}\right] .[\alpha]_{\mathrm{D}}{ }^{22}=-3.92\left(c 1.0, \mathrm{CHCl}_{3}, 74 \%\right.$ ee $)$. The ${ }^{1} \mathrm{H}$ and

${ }^{13} \mathrm{C}$ NMR spectra are consistent with values previously reported 80 in the literature. ${ }^{[8 b]}$

\section{(R)-Diphenyl 1-(4-methoxyphenyl)-2-nitroethylphosphonate} (7c)

Following the general procedure, compound 7c was obtained after 3 days at $-10{ }^{\circ} \mathrm{C}$ as a white solid in $79 \%$ yield. M.p.

${ }_{85} 133-137^{\circ} \mathrm{C}$. The ee of the product was determined by HPLC using a Daicel Chiralpak IB column ( $n$-hexane $/ i-\mathrm{PrOH}=90: 10$, flow rate $1 \mathrm{~mL} / \mathrm{min}, \lambda=254 \mathrm{~nm}$ ): $\tau_{\text {major }}=28.2 \mathrm{~min} ; \tau_{\text {minor }}=22.9$ min. HRMS calcd $\mathrm{C}_{21} \mathrm{H}_{20} \mathrm{NNaO}_{6} \mathrm{P} 436.0926$; found $436.0920\left[\mathrm{M}^{+}\right.$ $+\mathrm{Na}] .[\alpha]_{\mathrm{D}}{ }^{22}=-0.48\left(c 1.0, \mathrm{CHCl}_{3}, 78 \%\right.$ ee $)$. The ${ }^{1} \mathrm{H}$ and ${ }^{13} \mathrm{C}$ ${ }_{90} \mathrm{NMR}$ spectra are consistent with values previously reported in the literature. ${ }^{[8 a, b]}$

\section{(R)-Diphenyl 1-(2-methoxyphenyl)-2-nitroethylphosphonate} (7d)

Following the general procedure, compound 7d was obtained 95 after 3 days at $-10{ }^{\circ} \mathrm{C}$ as a white solid in $75 \%$ yield. M.p. $85-88^{\circ} \mathrm{C}$. The ee of the product was determined by HPLC using a Daicel Chiralpak IB column ( $n$-hexane $/ i-\mathrm{PrOH}=90: 10$, flow rate $1 \mathrm{~mL} / \mathrm{min}, \lambda=254 \mathrm{~nm}): \tau_{\text {major }}=17.6 \mathrm{~min} ; \tau_{\text {minor }}=13.3 \mathrm{~min}$. HRMS calcd for $\mathrm{C}_{21} \mathrm{H}_{20} \mathrm{NNaO}_{6} \mathrm{P}$ 436.0926; found 436.0929 $100\left[\mathrm{M}^{+}+\mathrm{Na}\right] .[\alpha]_{\mathrm{D}}{ }^{22}=+10.5\left(c 1.0, \mathrm{CHCl}_{3}, 73 \%\right.$ ee $)$. The ${ }^{1} \mathrm{H}$ and

${ }^{13} \mathrm{C}$ NMR spectra are consistent with values previously reported in the literature. ${ }^{[8 a, b]}$ 
(R)-Diphenyl 2-nitro-1-(2-

trifluoromethyl)phenyl)ethylphosphonate (7e)

Following the general procedure, compound 7e was obtained after 3 days at $-10{ }^{\circ} \mathrm{C}$ as a viscous yellow liquid in $79 \%$ yield. 5 The ee of the product was determined by HPLC using a Daicel Chiralpak IB column ( $n$-hexane $/ i-\mathrm{PrOH}=90: 10$, flow rate 1 $\mathrm{mL} / \mathrm{min}, \lambda=254 \mathrm{~nm}$ ): $\tau_{\text {major }}=14.1 \mathrm{~min} ; \tau_{\text {minor }}=10.5 \mathrm{~min}$. HRMS calcd for $\mathrm{C}_{21} \mathrm{H}_{17} \mathrm{~F}_{3} \mathrm{NNaO}_{5} \mathrm{P}$ 474.0694; found 474.0684 [M+ $\left.\mathrm{M}^{+}+\mathrm{Na}\right]$. $[\alpha]_{\mathrm{D}}^{22}=+10.3\left(c 1.0, \mathrm{CHCl}_{3}, 76 \%\right.$ ee $) .{ }^{1} \mathrm{H}$ NMR $(400 \mathrm{MHz}$, $\left.{ }_{10} \mathrm{CDCl}_{3}\right) \delta 4.90\left(\mathrm{ddd},{ }^{2} J_{\mathrm{H}-\mathrm{P}}=24.3,{ }^{3} J_{\mathrm{H}-\mathrm{H}}=9.6,{ }^{3} J_{\mathrm{H}-\mathrm{H}}=5.3 \mathrm{~Hz}, 1 \mathrm{H}\right.$, $\mathrm{CH}), 5.02-5.10\left(\mathrm{~m}, 1 \mathrm{H}, \mathrm{CH}_{2}\right), 5.19-5.26\left(\mathrm{~m}, 1 \mathrm{H}, \mathrm{CH}_{2}\right), 6.64-6.65$ (m, 1H, Ar), 6.65-6.67 (m, 1H, Ar), 7.01-7.06 (m, 1H, Ar), 7.097.16 (m, 4H, Ar), 7.17-7.22 (m, 1H, Ar), 7.30-7.35 (m, 2H, Ar), 7.42-7.47 (m, 1H, Ar), 7.53-7.57 (m, 1H, Ar), 7.72-7.74 (m, $1 \mathrm{H}$, $\left.{ }_{15} \mathrm{Ar}\right), 7.82-7.84(\mathrm{~m}, 1 \mathrm{H}, \mathrm{Ar}) .{ }^{13} \mathrm{C} \mathrm{NMR}\left(75 \mathrm{MHz}, \mathrm{CDCl}_{3}\right) \delta 38.8$ $(\mathrm{d}, J=143.4 \mathrm{~Hz}), 75.4(\mathrm{~d}, J=2.3 \mathrm{~Hz}), 119.7(\mathrm{~d}, J=4.6 \mathrm{~Hz})$, $120.4(\mathrm{~d}, J=4.1 \mathrm{~Hz}), 125.3(\mathrm{~d}, J=1.2 \mathrm{~Hz}), 125.9(\mathrm{~d}, J=1.2 \mathrm{~Hz})$, $127.1(\mathrm{~m}), 128.9(\mathrm{~d}, J=3.5 \mathrm{~Hz}), 129.6,129.6,129.7,129.8$, $130.0(\mathrm{~d}, J=1.2 \mathrm{~Hz}), 132.5(\mathrm{~d}, J=3.5 \mathrm{~Hz}), 147.8(\mathrm{~d}, J=9.8 \mathrm{~Hz})$, $20148.1(\mathrm{~d}, J=9.3 \mathrm{~Hz})$.

\section{(R)-Diphenyl 1-(4-chlorophenyl)-2-nitroethylphosphonate (7f)}

Following the general procedure, compound $7 \mathbf{f}$ was obtained after 3 days at $-10{ }^{\circ} \mathrm{C}$ as a white solid in $87 \%$ yield. M.p. $134-137^{\circ} \mathrm{C}$. The ee of the product was determined by HPLC using a Daicel ${ }_{25}$ Chiralpak IB column ( $n$-hexane $/ i$-PrOH $=90: 10$, flow rate 1 $\mathrm{mL} / \mathrm{min}, \lambda=254 \mathrm{~nm}): \tau_{\text {major }}=28.9 \mathrm{~min} ; \tau_{\text {minor }}=17.8 \mathrm{~min}$. HRMS calcd for $\mathrm{C}_{20} \mathrm{H}_{17} \mathrm{ClNNaO}_{5} \mathrm{P} 440.0431$; found $440.0430\left[\mathrm{M}^{+}+\right.$ Na]. $[\alpha]_{\mathrm{D}}{ }^{22}=-6.2$ (c 1.0, $\mathrm{CHCl}_{3}, 73 \%$ ee). The ${ }^{1} \mathrm{H}$ and ${ }^{13} \mathrm{C} \mathrm{NMR}$ spectra are consistent with values previously reported in the 30 literature. ${ }^{[8]}$

\section{(R)-Diphenyl 1-(4-fluorophenyl)-2-nitroethylphosphonate (7g)}

Following the general procedure, compound $\mathbf{7 g}$ was obtained after 4 days at $-10{ }^{\circ} \mathrm{C}$ as a white solid in $60 \%$ yield. M.p. $130-134{ }^{\circ} \mathrm{C}$. The ee of the product was determined by HPLC 35 using a Daicel Chiralpak IB column ( $n$-hexane $/ i-\mathrm{PrOH}=90: 10$, flow rate $1 \mathrm{~mL} / \mathrm{min}, \lambda=254 \mathrm{~nm}$ ): $\tau_{\text {major }}=26.7 \mathrm{~min} ; \tau_{\text {minor }}=15.0$ min. HRMS calcd for $\mathrm{C}_{20} \mathrm{H}_{17} \mathrm{FNNaO}_{5} \mathrm{P}$ 424.0726; found $424.0724\left[\mathrm{M}^{+}+\mathrm{Na}\right] .[\alpha]_{\mathrm{D}}^{22}=+0.23\left(c 1.0, \mathrm{CHCl}_{3}, 72 \%\right.$ ee $)$. The ${ }^{1} \mathrm{H}$ and ${ }^{13} \mathrm{C}$ NMR spectra are consistent with values previously 40 reported in the literature. ${ }^{[\mathrm{a}]}$

\section{(S)-Diphenyl 1-(furan-2-yl)-2-nitroethylphosphonate (7h)}

Following the general procedure, compound $\mathbf{7 h}$ was obtained after 3 days at $-10{ }^{\circ} \mathrm{C}$ as a white solid in $67 \%$ yield. M.p. $82-85^{\circ} \mathrm{C}$. The ee of the product was determined by HPLC using a ${ }_{45}$ Daicel Chiralpak IB column ( $n$-hexane $/ i-\mathrm{PrOH}=90: 10$, flow rate $1 \mathrm{~mL} / \mathrm{min}, \lambda=254 \mathrm{~nm}): \tau_{\text {major }}=21.8 \mathrm{~min} ; \tau_{\text {minor }}=12.1 \mathrm{~min}$. HRMS calcd for $\mathrm{C}_{18} \mathrm{H}_{16} \mathrm{NNaO}_{6} \mathrm{P} 396.0613$; found $396.062\left[\mathrm{M}^{+}+\right.$ $\mathrm{Na}] .[\alpha]_{\mathrm{D}}{ }^{22}=-9.0$ (c 1.0, $\mathrm{CHCl}_{3}, 76 \%$ ee). The ${ }^{1} \mathrm{H}$ and ${ }^{13} \mathrm{C} \mathrm{NMR}$ spectra are consistent with values previously reported in the ${ }_{50}$ literature. ${ }^{[\mathrm{a}, \mathrm{b}]}$

(R)-Diphenyl 1-(4-bromophenyl)-2-nitroethylphosphonate (7i)

Following the general procedure, compound $7 \mathbf{i}$ was obtained after 3 days at $-10{ }^{\circ} \mathrm{C}$ as a white solid in $79 \%$ yield. M.p. $134-137^{\circ} \mathrm{C}$. The ee of the product was determined by HPLC using a Daicel
${ }_{55}$ Chiralpak IB column ( $n$-hexane $/ i$-PrOH $=90: 10$, flow rate $1 \mathrm{~mL} / \mathrm{min}, \lambda=254 \mathrm{~nm}): \tau_{\text {major }}=30.6 \mathrm{~min} ; \tau_{\text {minor }}=21.0 \mathrm{~min}$. HRMS calcd for $\mathrm{C}_{20} \mathrm{H}_{17} \mathrm{BrNNaO}_{5} \mathrm{P}$ 483.9925; found 483.9960 $\left[\mathrm{M}^{+}+\mathrm{Na}\right] .[\alpha]_{\mathrm{D}}{ }^{22}=-8.7$ (c 1.0, $\mathrm{CHCl}_{3}, 76 \%$ ee $)$. The ${ }^{1} \mathrm{H}$ and ${ }^{13} \mathrm{C}$ NMR spectra are consistent with values previously reported in 60 the literature. ${ }^{[8 a, b]}$

\section{(R)-Diphenyl 1-(4-(benzyloxy)phenyl)-2- nitroethylphosphonate $(7 \mathbf{j})$}

Following the general procedure, compound $7 \mathbf{j}$ was obtained after 3 days at $-10{ }^{\circ} \mathrm{C}$ as a yellow solid in $81 \%$ yield. M.p. $122-126^{\circ} \mathrm{C}$. ${ }_{65}$ The ee of the product was determined by HPLC using a Daicel Chiralpak IB column ( $n$-hexane $/ i-\mathrm{PrOH}=90: 10$, flow rate $1 \mathrm{~mL} / \mathrm{min}, \lambda=254 \mathrm{~nm}): \tau_{\text {major }}=40.2 \mathrm{~min} ; \tau_{\text {minor }}=28.1 \mathrm{~min}$. HRMS calcd for $\mathrm{C}_{27} \mathrm{H}_{24} \mathrm{NNaO}_{6} \mathrm{P}$ 512.1239; found $512.1242\left[\mathrm{M}^{+}\right.$ $+\mathrm{Na}] .[\alpha]_{\mathrm{D}}{ }^{22}=-1.0\left(c 1.0, \mathrm{CHCl}_{3}, 78 \%\right.$ ee $) .{ }^{1} \mathrm{H}$ NMR $(400 \mathrm{MHz}$, $\left.{ }_{70} \mathrm{CDCl}_{3}\right) \delta 4.37\left(\mathrm{ddd},{ }^{2} J_{\mathrm{H}-\mathrm{P}}=24.5,{ }^{3} J_{\mathrm{H}-\mathrm{H}}=11.1,{ }^{3} J_{\mathrm{H}-\mathrm{H}}=4.6 \mathrm{~Hz}, 1 \mathrm{H}\right.$, $\mathrm{CH}), 5.00-5.10\left(\mathrm{~m}, 1 \mathrm{H}, \mathrm{CH}_{2}\right), 5.04\left(\mathrm{~s}, 2 \mathrm{H}, \mathrm{OCH}_{2}\right), 5.13-5.19(\mathrm{~m}$, $\left.1 \mathrm{H}, \mathrm{CH}_{2}\right), 6.75-6.77(\mathrm{~m}, 2 \mathrm{H}, \mathrm{Ar})$, 6.95-6.95 (m, 2H, Ar), 7.077.10 (m, 3H, Ar), 7.15-7.20 (m, 3H, Ar), 7.28-7.43 (m, 9H, Ar). ${ }^{13} \mathrm{C} \mathrm{NMR}\left(100 \mathrm{MHz}, \mathrm{CDCl}_{3}\right) \delta 42.7(\mathrm{~d}, J=141.9 \mathrm{~Hz}), 70.1,75.2$ $75(\mathrm{~d}, J=5.9 \mathrm{~Hz}), 115.6(\mathrm{~d}, J=2.2 \mathrm{~Hz}), 115.8,120.2(\mathrm{~d}, J=4.4$ $\mathrm{Hz}), 120.4$ (d, $J=4.4 \mathrm{~Hz}), 122.5(\mathrm{~d}, J=8.1 \mathrm{~Hz}), 125.5,125.6(\mathrm{~d}$, $J=24.2 \mathrm{~Hz}), 127.5,128.1,128.7,129.7,130.0,136.6,130.5$ (d, $J$ $=6.6 \mathrm{~Hz}), 149.9(\mathrm{~d}, J=10.2 \mathrm{~Hz}), 150.0(\mathrm{~d}, J=9.5 \mathrm{~Hz}), 159.2(\mathrm{~d}$, $J=2.9 \mathrm{~Hz})$.

\section{${ }_{80}$ (R)-Diphenyl 1-cyclohexyl-2-nitroethylphosphonate (7k)}

Following the general procedure, compound $\mathbf{7 k}$ was obtained after 3 days at $-10{ }^{\circ} \mathrm{C}$ as a white solid in $82 \%$ yield. M.p. $108-111^{\circ} \mathrm{C}$. The ee of the product was determined by HPLC using a Daicel Chiralpak IB column ( $n$-hexane $/ i$-PrOH $=90: 10$, 85 flow rate $1 \mathrm{~mL} / \mathrm{min}, \lambda=254 \mathrm{~nm}$ ): $\tau_{\text {major }}=7.5 \mathrm{~min} ; \tau_{\text {minor }}=6.7 \mathrm{~min}$. HRMS calcd for $\mathrm{C}_{20} \mathrm{H}_{24} \mathrm{NNaO}_{5} \mathrm{P}$ 412.1290; found $412.1290\left[\mathrm{M}^{+}\right.$ $+\mathrm{Na}] \cdot[\alpha]_{\mathrm{D}}{ }^{22}=-8.27$ (c 1.0, $\mathrm{CHCl}_{3}, 72 \%$ ee). The ${ }^{1} \mathrm{H}$ and ${ }^{13} \mathrm{C}$ NMR spectra are consistent with values previously reported in the literature. ${ }^{[8 b]}$

\section{0 (R)-Diphenyl 1-nitro-4-phenylbutan-2-ylphosphonate (7l)}

Following the general procedure, compound $7 \mathbf{l}$ was obtained after 3 days at $-10^{\circ} \mathrm{C}$ as a white solid in $60 \%$ yield. M.p. $70-75^{\circ} \mathrm{C}$. The ee of the product was determined by HPLC using a Daicel Chiralpak IA column ( $n$-hexane $/ i-\mathrm{PrOH}=95: 5$, flow rate $951 \mathrm{~mL} / \mathrm{min}, \lambda=254 \mathrm{~nm}): \tau_{\text {major }}=43.1 \mathrm{~min} ; \tau_{\text {minor }}=47.1 \mathrm{~min}$. HRMS calcd for $\mathrm{C}_{22} \mathrm{H}_{22} \mathrm{NNaO}_{5} \mathrm{P} 434.1133$; found $434.1145\left[\mathrm{M}^{+}\right.$ $+\mathrm{Na}] .[\alpha]_{\mathrm{D}}{ }^{22}=+4.70\left(c 1.0, \mathrm{CHCl}_{3}, 68 \%\right.$ ee $)$. The ${ }^{1} \mathrm{H}$ and ${ }^{13} \mathrm{C}$ NMR spectra are consistent with values previously reported in the literature. ${ }^{[8 c]}$

\section{${ }_{100}$ Notes and references}

a Laboratorio de Síntesis Asimétrica, Departamento de Química Orgánica. Instituto de Ciencia de Materiales de Aragón.

Universidad de Zaragoza-CSIC. E-50009 Zaragoza, Aragón, Spain Fax:+34 976762075; Tel: +34 976762281; E-mail: raquelph@unizar.es $105{ }^{b}$ Organische Chemie, Technische Universität Dortmund, Otto-Hahn-Str. 6. 44227 Dortmund, Germany

${ }^{c}$ ARAID, Fundación Aragón I+D, E-50004 Zaragoza, Spain

$\uparrow$ Electronic Supplementary Information (ESI) available: Detailed experimental procedures and characterization data for new compounds 
7e,j and HPLC chromatograms for all compounds 7a-l. See DOI: $10.1039 / \mathrm{b} 000000 \mathrm{x} /$

1 Asymmetric Synthesis: The Essentials, $2^{\text {nd }}$ edition (Eds.: M. Christmann, S. Bräse), Wiley-VCH, Weinheim, Germany, 2007.

2 For selected reviews on organocatalysis, see for example: (a) P. I. Dalko, L. Moisan, Angew. Chem. Int. Ed., 2004, 43, 5138; (b) A Berkessel, H. Gröger, Asymmetric Organocatalysis, Whiley-VHC, Weinheim, Germany, 2004; (c) Acc. Chem. Res., 2004, 37 (8), special issue on organocatalysis; (d) J. Seayed, B. List, Org. Biomol. Chem., 2005, 3, 719; (d) Enantioselective Organocatalysis (Ed.: P. I. Dalko), Whiley-VCH: Weinheim, Germany, 2007; (e) Chem. Rev., 2007, 107 (12), special issue on organocatalysis; $(f)$ A. Dondoni, A. Massi, Angew. Chem. Int. Ed., 2008, 47, 4638; $(g)$ P. Melchiorre, M. Marigo, A. Carlone, G. Bartoli, Angew. Chem. Int. Ed., 2008, 47, 6138; (h) A. Mielgo, C. Palomo, Chem. Asian J., 2008, 3, 922; $(i)$ Asymmetric Phase Transfer Catalysis (Ed.: K. Maruoka), WileyVCH, Weinheim, 2008; (j) S. Bertelsen, K. A. Jørgensen, Chem. Soc. Rev., 2009, 38, 2178.

203 For applications of organocatalysis in the synthesis of natural products and non-natural biologically active molecules, see: $(a)$ R. M. de Figueiredo, M. Christmann, Eur. J. Org. Chem., 2007, 2575; (b) E. Marqués-López, R. P. Herrera, M. Christmann, Nat. Prod. Rep., 2010, 27, 1138

${ }_{25} 4$ For a recent review about $\beta$-aminophosphonic acids, see: $M$ Ordóñez, H. Rojas-Cabrera, C. Cativiela, Tetrahedron, 2009, 65, 17.

5 For a review on $\alpha$-aminophosphonic acids, see: F. Palacios, C. Alonso, J. M. de los Santos, Chem. Rev., 2005, 105, 899.

6 For the biological activity of $\alpha$-aminophosphonic acids, see:

30 Aminophosponic and aminophosphinic acids: Chemistry and Biological Activity (Eds.: V. P. Kukhar, H. R. Hudson), Wiley, NY, 2000 .

7 For reviews about enantioselective synthesis of $\alpha$-aminophosphonate derivatives, see: (a) J.-A. Ma, Chem. Soc. Rev., 2006, 35, 630; (b) P. Merino, E. Marqués-López, R. P. Herrera, Adv. Synth. Catal., 2008 350, 1195

8 (a) J. Wang, L. D. Heikkinen, H. Li, L. Zu, W. Jiang, H. Xie, W. Wang, Adv. Synth. Catal., 2007, 349, 1052; (b) M. Terada, T. Ikehara, H. Ube, J. Am. Chem. Soc., 2007, 129, 14112. This work was published during the preparation of this manuscript: (c) Y. Zhu, J. P. Malerich, V. H. Rawal, Angew. Chem. Int. Ed., 2010, 49, 153

9 For a recent review of phospha-Michael reaction with electron deficient alkenes, see: D. Enders, A. Saint-Dizier, M.-I. Lannou, A. Lenze, Eur. J. Org. Chem., 2006, 29.

4510 For organocatalytic enantioselective Michael addition reactions of other phosphorus nucleophiles using electron deficient alkenes, see: (a) G. Bartoli, M. Bosco, A. Carlone, M. Locatelli, A. Mazzanti, L. Sambri, P. Melchiorre, Chem. Commun., 2007, 722; (b) A. Carlone, G. Bartoli, M. Bosco, L. Sambri, P. Melchiorre, Angew. Chem. Int.

50 Ed., 2007, 46, 4504; (c) I. Ibrahem, R. Rios, J. Vesely, P. Hammar, L. Eriksson, F. Himo, A. Códova, Angew. Chem. Int. Ed., 2007, 46, 4507; (d) E. Maerten, S. Cabrera, A. Kjaersgaard, K. A. Jørgensen, J Org. Chem., 2007, 72, 8893; (e) S. Wen, P. Li, H. Wu, F. Yu, X Liang, J. Ye, Chem. Commun., 2010, 46, 4806; (f) T. S. Pham, L. Balázs, I. Petneházy, Z. Jászay, Tetrahedron: Asymmetry, 2010, 21 346. For 1,4-addition reaction of nitoalkenes with dialkyl phosphites catalyzed by achiral guanidine derivatives, see: $(g)$ Z. Jiang, Y. Zhang, W. Ye, C.-H. Tan, Tetrahedron Lett., 2007, 48, 51.

11 (a) D. P. Curran, L. H. Kuo, J. Org. Chem., 1994, 59, 3259; (b) D. P. Curran, L. H. Kuo, Tetrahedron Lett., 1995, 36, 6647.

12 (a) P. R. Schreiner, Chem. Soc. Rev., 2003, 32, 289; (b) Y. Takemoto Y. Takemoto, Org. Biomol. Chem., 2005, 3, 4299; (c) S. J. Connon, Chem. Eur. J., 2006, 12, 5418; (d) M. S. Taylor, E. N. Jacobsen, Angew. Chem. Int. Ed., 2006, 45, 1520; (e) A. G. Doyle, E. N Jacobsen, Chem. Rev., 2007, 107, 5713; (f) Z. Zhang, P. R. Schreiner, Chem. Soc. Rev., 2009, 38, 1187; $(g)$ E. Marqués-López, R. P. Herrera, An. Quim., 2009, 105, 5.

13 (a) G. Dessole, R. P. Herrera, A. Ricci, Synlett, 2004, 2374-2378; (b) R. P. Herrera, V. Sgarzani, L. Bernardi A. Ricci, Agew. Chem. Int

$70 E d .$, 2005, 44, 6576; (c) D. Pettersen, R. P. Herrera, L. Bernardi, F. Fini, V. Sgarzani, R. Fernández, J. M. Lassaletta, A. Ricci, Synlett,
2006, 239; (d) L. Bernardi, F. Fini, R. P. Herrera, A. Ricci, V. Sgarzani, Tetrahedron, 2006, 62, 375; (e) R. P. Herrera, D. Monge, E. Martín-Zamora, R. Fernández, J. M. Lassaletta, Org. Lett., 2007, 9, 3303.

14 For the recognition of the nitro group by urea moieties, see: (a) M. C. Etter, T. W. Panunto, J. Am. Chem. Soc., 1988, 110, 5896; (b) M. C. Etter, Z. Urbañczyk-Lipkowska, M. Zia-Ebrahimi, T. W. Panunto, J. Am. Chem. Soc., 1990, 112, 8415; (c) T. R. Kelly, M. H. Kim, J. Am. Chem. Soc., 1994, 116, 7072.

15 For selected examples, see: $(a)$ J. Wang, H. Li, W. Duan, L. Zu, W. Wang, Org. Lett., 2005, 7, 4713; (b) H. Huang, En. N. Jacobsen, J. Am. Chem. Soc., 2006, 128, 7170; (c) D. A. Yalalov, S. B. Tsogoeva, S. Schmatz, Adv. Synth. Catal., 2006, 348, 826; (d) Z. Zhang, P. R.

85 Schreiner, Synthesis, 2007, 2559; (e) Z.-H. Zhang, X.-Q. Dong, D. Chen, C.-J. Wang, Chem. Eur. J., 2008, 14, 8780.

16 For the first examples using catalyst 4a, see: $(a)$ T. Okino, Y. Hoashi, Y. Takemoto, J. Am. Chem. Soc., 2003, 125, 12672; (b) T. Okino, S. Nakamura, T. Furukawa, Y. Takemoto, Org. Lett., 2004, 6, 625; (c)

90 T. Okino, Y. Hoashi, T. Furukawa, X. Xu, Y. Takemoto, J. Am. Chem. Soc., 2005, 127, 119.

17 In absence of $i \operatorname{Pr}_{2} \mathrm{EtN}$ we did not observe the final adduct after 3 days of reaction.

18 For examples of use of $\mathbf{4 h}$ as bifunctional catalyst, see: (a) D. Pettersen, F. Piana, L. Bernardi, F. Fini, M. Fochi, V. Sgarzani, A. Ricci, Tetrahedron Lett., 2007, 48, 7805; (b) H. S. Rho, S. H. Oh, J. W. Lee, J. Y. Lee, J. Chin, C. E. Song, Chem. Commun., 2008, 1208; (c) D. R. Li, A. Murugan, J. R. Falck, J. Am. Chem. Soc., 2008, 130, 46.

10019 (a) Y. Sohtome, A. Tanatani, Y. Hashimoto, K. Nagasawa, Tetrahedron Lett., 2004, 45, 5589. (b) Y. Zhang, Y.-K. Liu, T.-R. Kang, Z.-K. Hu, Y.-C. Chen, J. Am. Chem. Soc., 2008, 130, 2456.

20 For the $\mathrm{p} K_{\mathrm{a}}$ 's values of different phosphorus nucleophiles, see: J.-N. Li, L. Liu, Y. Fu, Q.-X. Guo, Tetrahedron, 2006, 19, 2335.

10521 R. P. Herrera, D. Roca-López, G. Navarro-Moros, Eur. J. Org. Chem., 2010, 1450.

22 For reviews about thioureas as bifunctional organocatalysts, see: $(a)$ H. Miyabe, Y. Takemoto, Bull. Chem. Soc. Jpn., 2008, 81, 785; (b) S. J. Connon, Chem. Commun., 2008, 2499.

11023 Y. Hoashi, T. Okino, Y. Takemoto, Angew. Chem. Int. Ed., 2005, 44, 4032.

24 All calculations were carried out with the Gaussian 09 suite of programs: Gaussian 09, Revision A.1, Frisch, M. J.; Trucks, G. W.; Schlegel, H. B.; Scuseria, G. E.; Robb, M. A.; Cheeseman, J. R.; Scalmani, G.; Barone, V.; Mennucci, B.; Petersson, G. A.; Nakatsuji, H.; Caricato, M.; Li, X.; Hratchian, H. P.; Izmaylov, A. F.; Bloino, J.; Zheng, G.; Sonnenberg, J. L.; Hada, M.; Ehara, M.; Toyota, K.; Fukuda, R.; Hasegawa, J.; Ishida, M.; Nakajima, T.; Honda, Y.; Kitao, O.; Nakai, H.; Vreven, T.; Montgomery, Jr., J. A.; Peralta, J. E.; Ogliaro, F.; Bearpark, M.; Heyd, J. J.; Brothers, E.; Kudin, K. N.; Staroverov, V. N.; Kobayashi, R.; Normand, J.; Raghavachari, K.; Rendell, A.; Burant, J. C.; Iyengar, S. S.; Tomasi, J.; Cossi, M.; Rega, N.; Millam, N. J.; Klene, M.; Knox, J. E.; Cross, J. B.; Bakken, V.; Adamo, C.; Jaramillo, J.; Gomperts, R.; Stratmann, R. E.; Yazyev, O.; Austin, A. J.; Cammi, R.; Pomelli, C.; Ochterski, J. W.; Martin, R. L.; Morokuma, K.; Zakrzewski, V. G.; Voth, G. A.; Salvador, P.; Dannenberg, J. J.; Dapprich, S.; Daniels, A. D.; Farkas, Ö.; Foresman, J. B.; Ortiz, J. V.; Cioslowski, J.; Fox, D. J. Gaussian, Inc., Wallingford CT, 2009

13025 (a) A. Hamza, G. Schubert, T. Soós, I. Pápai, J. Am. Chem. Soc., 2006, 128, 13151; (b) R. Zhu, D. Zhang, J. Wu, C. Liu, Tetrahedron: Asymmetry, 2006, 17, 1611; (c) P. Hammar, T. Marcelli, H. Hiemstra, F. Himo, Adv. Synth. Catal., 2007, 349, 2537.

26 B.-L. Li, Y.-F. Wang, S.-P. Luo, A.-G. Zhong, Z.-B. Li, X.-H. Du, D.-Q. Xu, Eur. J. Org. Chem., 2010, 656.

27 For the single enantioselective Michael addition reaction of dialkyl phosphites to nitroalkenes catalyzed by aluminum lithiumbis(binaphthoxide), see: V. Rai, I. N. N. Namboothiri, Tetrahedron: Asymmetry, 2008, 19, 2335.

14028 E. M. Fleming, T. McCabe, S. J. Connon, Tetrahedron Lett., 2006, 47, 7037

29 B. Vakula, S. Varga, A. Csámpai, T. Soós, Org. Lett., 2005, 7, 1967. 